\title{
Youth-to-Youth Engagement
}

\author{
Mohd Suhaimi Mohamad, Rozita Ibrahim, Daniella M. Mokhtar, Nasrudin Subhi
}

\begin{abstract}
Youth-to-youth engagement develops as well as enhances sense of belonging, autonomy and power control, competence, motivation and decision-making skills. Millennial youth are self-learned generation; thus, peer influence is vital. Based on these premises, GENIUS Remaja programmes are created 'with youths' rather than 'for youth'. GENIUS Remaja programmes have proven to be effective and produced positive results for the participants. Empowerment of youth through personal development trainings as well as participation in addressing community needs help them to become empathic and reflective individuals. Besides that, the programmes instilled good work ethics to ensure success in their future careers. Aspects of rethinking behaviour modification and intervention among reckless bikers (Mat Rempit) via youth-to-youth engagement in positive activities will be explored and shared in this article.
\end{abstract}

Index Terms: GENIUS Remaja, youth empowerment, youth-to-youth empowerment.

\section{INTRODUCTION}

Youth engagement is not just an idea to move young people into development but also to change the focus on how organisations and communities should connect with youth. There are many organisations and institutions such as schools, colleges, youth centres, foundations, and human services agencies that are working with youths. Youth engagement programmes need to involve young persons into activities that have meaningful participation for them. Youth engagement programmes also need to sustain youths' involvement.

Among the activities that are usually associated with youths are sports, music, volunteerism, culture and arts, as well as politics and social activism. These activities can occur at various settings and levels of the society i.e. the community, district, state, national or international levels. There are many ways that can indicate youth engagement, for example, when he or she frequently spends time and is involved with organisations' activities (community, youth, ethnic/culture); he/she is sharing information about the activity/organisation with others or even initiates the activity him/herself.

Revised Manuscript Received on September 25, 2019

Mohd. Suhaimi Mohamad, School of Human and Societal Well-being, Universiti Kebangsaan Malaysia.

Rozita Ibrahim, Centre for Liberal Studies (Pusat Citra), Universiti Kebangsaan Malaysia.

Daniella M. Mokhtar, School of Human and Societal Well-being, Universiti Kebangsaan Malaysia.

Nasrudin Subhi, School of Human and Societal Well-being, Universiti Kebangsaan Malaysia.
However, not all youths are engaged in youth's activities or organisations and their level of involvements varies and come in many different ways. Some youths might attend meetings or activities conducted by youth's organisations without necessarily involved as active participants. Usually, the ones who are active participants were the leaders. Therefore, there is a need for researchers to study the impact of youth activities or programmes and try to understand how to gain active participations of all youths involved.

Researchers need to understand why some programmes failed to engage youths? Why do some youths inclined towards getting involved in social problems, despite the many youth engagement efforts practised in the past few decades? There is no one solid answer to these questions, but a common respond is that we failed to understand the needs of young people. A lot of youth activities or programmes are organised based on 'deficit perspective'. For example, youth workers in the past were focused on what they think and believe is important for youth. Youth are often disconnected from development, and these activities or programmes were focused "for" youth rather than "with" youth [3] [8].

Therefore, it is timely that we look at youths as important assets for the society and try to engage them into development programmes through the strength-based perspectives. In this paper, we discuss the need for youth development programmes especially for at-risk groups of B40 community. We also share our experiences on the GENIUS@remaja Camp programme formerly known as PERKASA@remaja Camp programme that is targeted for at-risk youth groups aged between 17 to 25 years old, particularly those who are involved in reckless bikers' groups or better known as Mat Rempit.

\section{LITERATURE REVIEW}

\section{A. Issuses of 'Mat Rempit'}

Mat Rempit, if translated to English is also known as 'hell-rider' [13] is a social issue among the youth mostly among the Malay youth aged 15 to 28 years old. This phenomenon occurs in groups which involves illegal racing which often puts the public in danger. Besides illegal racing, these riders/ bikers practice dangerous stunts on their motorcycle that has been illegally 'altered'. Their activities then expand to more criminal activities like stealing, drug abuse and other social crimes allowing them to be perceived as aggressive and wild by the public. In general, the public perceives this groups of Mat Rempit as something that is 'counterculture' as it is

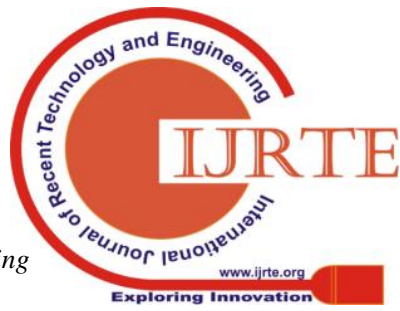




\section{Youth - to Youth Engagement}

considered to reject the general norms and in order to pursue an alternative lifestyle [5].

An interview among reckless bikers revealed that their involvement in reckless riding are due to several factors including being influenced by peers, take up as hobbies, treated it as recreational, life pressure/ a way of releasing their stress, a way for them to gain income (from race wins) [7]. These factors present the need for activities that youth may stay engaged in. Youth engaging with activities or programmes can be a challenge especially among those who are at-risk.

This is due to a few reasons where youth are often disconnected or distracted and sometimes have trust issues with the support systems within the society [1] [4] [9]. Nevertheless, youth engagement remains as one of the key contributors to positive outcomes at various levels including personal (i.e identity and empowerment), social (i.e. social or cultural identity, sense of belongingness) and the society [2] [18].

\section{B. The Need For Youth-To-Youth Developmental Programmes}

World Youth Report (2005) [17] reported that about 25\% of young people were identified as at-risk youth. They are involved with delinquency because of their marginalised life, low socio-economy status and the lack of opportunity to realise their potentials. They are prone to engage in juvenile and social problems because of their impoverished backgrounds. In Malaysia, there are about $11.5 \%$ of the Malaysian youths have been involved in deviant behaviours as reported in the Malaysia Youth Index 2015 [5]. This percentage is still considered low and only a handful is considered at-risk youths. However, with the advancement of technology and the complexity of social problems, it is not impossible that this percentage might increase dramatically. This situation can be seen in the increasing number of youths involved in social problems such as drug abuse, juvenile delinquency, HIV transmissions, pre-marital sexual activities, reckless riding (rempit) and street crimes.

In parallel, the number of youths who dropped out from school is also increasing, which according to the Educational Planning and Research Division (EPRD), the dropout rate increased from 1.92 in 2012 to 1.96 in 2013 (Malaysia Ministry of Education 2014) [6]. About $75 \%$ upper secondary school students (15 years to 17 years) who dropped out are those categorised as the bottom-40 (B40) group. Malaysian Government through the Economy Planning Unit (EPU) give serious attention to the B40 youths by providing them various facilities through the Tenth Malaysia Plan (2011-2015) to address the educational needs and skills attainment. For example, the implementation of 1Asrama and Asrama Desa programmes which help reduce student dropout cases. As of 2014, 1.51 million students benefited from financial aid including Kumpulan Wang Amanah Pelajar Miskin (KWAPM) and Rancangan Makanan Tambahan (RMT). In addition, various social safety net initiatives were implemented to reduce vulnerability and protect the livelihood of B40 households from economic shocks. These include housing assistance such as Programme Bantuan Rumah (PBR), Rumah Mesra Rakyat and Rumah Mampu Milik to 55,000 households. However, youth who are living in public housing are at-risk due to overcrowding and lack of youth activities/programmes that interest them. Again, they are deprived of prospects for improving their lives and becoming dependable and responsible adults. Indeed, they are victims of an environment which stifles their true potential. To address this issue, an approach is suggested so that youth's talents, rather their common problems, become the organising element behind their participation in intervention programme such as GENIUS@Remaja programmes.

\section{METHODOLOGY}

\section{A. Establishments Of The Genius Remaja Programmes}

Youth development is important to a nation in many ways and serves as a key indicator to the state of the nation. Youth development is expected to reflect the economic situation; shifts in cultural values over sexuality, morality and family life; the concept of nationhood; and occupational structures. Although many agree that young people are important actors in a country's progress, there are instances when they are marginalized and excluded from participating fully in society and its institutions. Studies have shown that those who have positive life experiences tend to be associated with a mainstream status, particularly with regard to secure income and employment.

On the other hand, those with negative life experiences tend to struggle with time, space, resources and identity formation. They also frequently exhibit anti-social behaviors. Some young people face difficulty in reconciling the reality of their circumstances and the pressure and promises of material wealth and well-being that an increasingly globalized society offers. It is against this background that GENIUS Remaja was established as part of the GENIUS programme initiated to address anti-social behaviours among youths. The idea was to develop an innovative social intervention programme that could produce a bold, dynamic, competitive and confident young generation. Therefore, the Youth Empowerment Centre (PERKASA) of UKM was entrusted with the tasks of instituting the intervention programmes targeting marginalised youths in urban communities and rehabilitating young people who have displayed negative social behaviours.

\section{B. Research Design}

To address these issues, two intervention programmes were adopted, i.e. preventive and curative. Preventive measures are more difficult to conceptualise, plan, implement and evaluate. Preventive measures are usually more proactive in nature and produce long-term and enduring results. Yet curative measures are absolutely necessary, since damages have been done to some unfortunate youths. Furthermore, curative measures are more popular, as they are easy to plan and implement, and they produce short-term effects. In short, both curative and preventive approaches are at the core of the GENIUS Remaja programmes.

This paper will only discuss the camp-based intervention programme conducted by 
GENIUS Remaja. The camp-based is a curative intervention programme for youths who are involved in reckless riding (rempit). The aim of the programmes is to develop the youth true potentials through holistic manner by integrating the emotional, intellectual, spiritual and vocational skills development. The programme's specific objectives are (1) to empower the participants by enhancing their self-esteem, resiliency, assertiveness and competencies; (2) to impart social, communication and vocational skills as part of their life-long survival skills; and (3) to instil the spirit of volunteerism and desire to give back to society.

Participation in GENIUS Remaja camp is based on voluntary basis. All youths who participated in this programme need to complete a written consent form. The participants were then placed in training camps to undergo a series of intervention programmes on emotional, spiritual, intellectual and behavioural development.

\section{Module Content of the GENIUS Remaja Camp}

The modules of GENIUS Remaja camp were developed by UKM multi-disciplinary research experts in the field of psychology, counselling, social work, youth development and religious studies. There are four modules for the GENIUS Remaja camp programme, i.e. Module 1: Self-development; Module 2: Leadership development and teamwork; Module 3: Skills development; and Module 4: Religion and spirituality. The GENIUS Remaja camp can be divided into five parts consisting of (i) the pre-camp (4 days), (ii) the first camp (5 days), (iii) the second camp (3 days); (iii) the third camp (7 days); (iv) the fourth camp (7 days); and (v) the open-camp (8 weeks).

During the pre-camp, participants need to undergo psychological and physiological profile screening. All participants are to complete personality and flow experience test; level of aggressiveness and sensational test; self-esteem test; emotional quotient (EQ) test; SQ test, mental health test; assertive and resiliency scale test; career interest test; and self-development and leadership test. This programme utilised a mixed method approach (quantitative and qualitative) in collecting data from the participants.

At the first camp, the participants will focus on awareness and self-development programmes that include components of trust, team building and self-exploration. The third camp will allow participants to learn about effective communication and how to control anger, through games and group activities. The third camp is a self-empowerment programme conducted at the outbound camp. The aims are to increase self-esteem, resilient, assertive behaviour and alignment of leadership competencies. The fourth camp is called 'iconic encounter' and involves youth-to-youth activities. The activities are meant to motivate participants to achieve success through sharing sessions by successful youths who act as role models. The last part of the GENIUS Remaja camp is the internship and intensive industrial training where participants will be assigned to selected industries based on their interests.

\section{RESULTS AND DISCUSSION}

Youth-to-youth programme provided positive results for the participants because they were involved throughout the initial stage up to the evaluation stage. This is essential to ensure that the voices of these youths could be heard at all stages of engaging them. Feedback from the participants is the key to success for any youth-to-youth programme. Positive changes also happened through transformative process in empowering youth to work with local agencies and to create good community ecosystems.

\section{A. Categories identified of at-risk youth}

One of the benefits of the GENIUS Remaja programme is that we can identify different categories of at-risk youth. In the case of Mat Rempit, three categories were identified namely the hard-core group, the intermediate or middle group, and the follower group. The hard-core group usually dominated all the activities and having the stubborn and rebellious characters. The middle group have a high compliance rate and are relatively positive in attitude, not easily influenced, do not like to fight. This middle group has a high potential for positive changes. Lastly, participants from the follower group usually follow other participants, less talkative and obedient. However, they are easily influenced and manipulated by the hard-core group.

According to this classification, we found that only a small part (the middle group) who really wants to change, and they have mostly been offered work and skills training to change their future. Upon completion of the camp, majority of the participants were offered skills training at Institut Kemahiran Belia Negara (IKBN) or Pusat Giat Mara. However, some participants had to decline the offer because they could not afford the time as they need to work in order to support their families. Others had to decline because the training institutes are far from their homes.

\section{B. Positive outcomes of the GENIUS Remaja Camp}

Generally, the camp managed to change attitudes, behaviour, cognitive and perception of youth about their lives even though the change is rather small. After the camp, some participants started diligently seeking for employment or participated in skills training. Participants were also seen to improve in terms of volunteerism and helping others as well as showing positive views towards their future lives. Most importantly, they no longer involved in 'rempit' activities as they are now busy with their work. The positive impacts of the GENIUS Remaja camp programme could be seen among the participants through their responses. For example:

"GENIUS Remaja camp is very good. This camp helped me change my attitude."

(Amir, 15 years old)

"GENIUS Remaja camp is great, it is fun, and I can learn many things in life, now I can continue to learn."

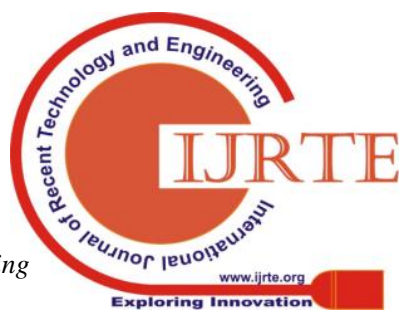




\section{Youth - to Youth Engagement}

(Firdaus, 17 years old)

"I am so fortunate to be able to enter the camp, and I can feel myself changing to the right path."

(Azni, 18 years old)

"I gained a lot of new experiences after attending this camp. Mat Rempit can change!"

(Leong, 17 years old)

\section{Future directions}

Results from the intervention has helped identified different categories of youth at-risk where behaviours were grouped according to is severity (i.e. hard-core, middle and followers). From this, it was observed that youth categorised in the middle group was prone to change and adapted lessons from their intervention. This brought us to the attention of moving away from the one-size-fits-all solution. Perhaps future interventions may provide specific modules tailored to these specific groups in which it may increase its effectiveness. However, it will require more time and costs in order to develop tailor-made modules.

GENIUS Remaja camp is one example of youth-to-youth engagement programme in this country. This research provides practical contributions based on its empirical findings. It has been proven that these youth at-risk although not all, but some do change for the better and disengage from unproductive activities such as 'rempit'. Therefore, various parties (i.e. family members, schools, society, government, media) should play their roles in encouraging programmes like these or improved ones in order to fulfil the needs of the 21 st century youth-to-youth engagement programmes.

We need to change our mind set from the deficit perspective into strength or asset-based perspective. The duration of youth programmes especially the youth camp has to be evaluated because time is needed in order to change youths' behaviour. Programmes cannot be a "touch-n-go" type and only adopt a top-down policy. Studies have proven that transformation of knowledge, awareness and attitude does not necessarily give rise to behavioural change [11] [14] [16]. Efforts must be initiated to identify why individuals resist change and what are the obstacles faced for one to accept change. Rahim (2014) noted that contemporary youth development efforts to reduce inequality by targeting the poorest segments of society, involving people in their own development, giving them independence from central authority, and employing "small" and "appropriate" technologies could be helpful in sustaining positive changes among youths [10].

\section{CONCLUSION}

In conclusion, youth-to-youth engagement programmes are crucial for our country's development. Young people should not be treated as liabilities that are involved in social

problems rather, they should be regarded as humans and assets for the nation. Youths should be included as partners in national development. With the talents and potentials existing in them, youths are capable of changing at-risk behaviour into positive behaviour.

In order to assist youths, we must start with ourselves by accepting and including these young people into community development programmes. Youths that are involved in these programmes can then talk to other youths and work towards positive change according to their ways. All parties have a role to collaborate in youth development or engagement programmes and should work together towards community development. Youth workers need to understand the needs of today's youth and equipped themselves with the latest knowledge and skills related to youth development. We want to move forward; not backward!

\section{ACKNOWLEDGMENT}

All authors acknowledge the financial support from the GENIUS Division, Ministry of Education Malaysia and Centre for Youth Empowerment (PERKASA), Universiti Kebangsaan Malaysia for their assistance in this research.

\section{REFERENCES}

1. Alicea,S., Pardo,G.,Conover,K.,Gopalan, G., \& McKay, M. "Step-up: Promoting youth mental health and development in inner-city high schools". Clinical Social Work Journal, vol. 40 no. 2,2012, pp. 175186.

2. Blanchet-Cohen, N., \& Salazar, J, "Empowering practices for working with marginalized youth", Relational Child \& Youth Care Practice, vol. 22 , no. 4,2009 , pp. 5-15.

3. Hazita, A., Bahiyah, A. H., \& Zarina, O, "Malaysian Youth in the Global World: Issues and Challenges", Bangi: Penerbit Universiti Kebangsaan Malaysia, 2011.

4. Jennings, L.B., Parra-Medina, D.M., Messias, D.K.H., \& McLoughlin, $\mathrm{K}$, "Toward a critical social theory of youth empowerment", Journal of Community Practice, vol.14 no.1-2, 2006, pp. 31-55.

5. Malaysian Youth Index, "Malaysian Institute for Research in Youth Development. Ministry of Youth and Sports, Putrajaya", 2015.

6. Ministry of Education, "Malaysia Education Blueprint Annual Reports 2013. Putrajaya", 2014

7. Muhamad Fuad Abdul Karim, Rokiah Ismail, and Mohamad Fauzi Sukimi, "Sub-budaya Mat Rempit dan Perubahan Sosiobudaya, Malaysian Journal of Society and Space", Vol.3, 2009, 26-43(In Malay) Injury Severity Analysis of Accidents Involving Young Motorcycle Riders in Malaysia.

8. Mohamed, I. A., \& Wheeler, W, "Broadening the bounds of youth development, youth as engaged citizens". The Innovation Center for Community and Youth Development and The Ford Foundation, 2001, pp. 1-15.

9. Pearrow, M.M, "A critical examination of an urban-based youth empowerment strategy: The teen empowerment program.", Journal of Community Practice, vol. 16, no.4, 2008, pp. 509-525.

10. Rahim, S. A, "Regenerating Youth Development: The Challenges for Development Communication" The Journal of Development Communication, 2014, 17-27.

11. Rogers, E, Diffusion of Innovation. New York. Free Press, 2003.

12. Rokiah Ismail, 'Kumpulan 'Mat Motor' dan perlumbaan motor haram: Suatu penelitian dari aspek sosiologi", Prosiding Seminar Kebangsaan Ke-3 Psikologi dan Masyarakat 2004. Pusat Teknologi Pendidikan, Universiti Kebangsaan Malaysia. 4-5 Oktober, 2004.

13. Rozmi Ismail, "Gejala perlumbaan motosikal haram di kalangan remaja: Peranan keluarga dan masyarakat dalam mengenai gejala ini”, Prosiding Seminar Kebangsaan Ke-3 Psikologi dan Masyarakat 2004. Pusat Teknologi Pendidikan, Universiti 
Kebangsaan Malaysia. 4-5 Oktober 2004

14. Rozmi Ismail. "Personaliti dan Salah laku di Kalangan Mat Rempit." A report submitted to the Malaysian Institute for Research in Youth Development, 2007.

15. Schaefer RT, "Sociology". Mc Graw Hill, New York, NY, 2003.

16. Singhal, A. "Turning Diffusion of Innovation Paradigm on its Head: The Positive Deviance Approach to Social Change". In Arun Vishwanath \& George Barnett (in press). Advances in the Study of the Diffusion of Innovation; Theory, Methods, and Application, 2010.

17. World Youth Report, Young People Today, and in 2015. United Nations, 2015.

18. Yohalem, N., \& Martin, S, "Building the evidence base for youth engagement: Reflections on youth and democracy", Journal of Community Psychology, vol. 35, no. 6, 2007, pp. 807-810.

\section{AUTHORS PROFILE}

\section{? \\ Dr. Mohd Suhaimi Mohamad ${ }^{1}$}

Mohd Suhaimi Mohamad is currently a senior lecturer at the School of Psychology and Human Well-being (PsiTra), Faculty of Social Sciences at The National University of Malaysia (UKM). He teaches and does research in the area of work that covers Mental Health, Community Social Work, Family Care and Education for Marginalized Group

\section{(2) \\ Dr. Rozita Ibrahim}

Rozita Ibrahim is currently a senior lecturer at the Centre for Liberal Studies (Pusat Citra) at The National University of Malaysia (UKM). She teaches various liberal studies courses such as Ethnic Relations, Family Issues and Global Ecology. Her research interests include religious studies, and environmental education.

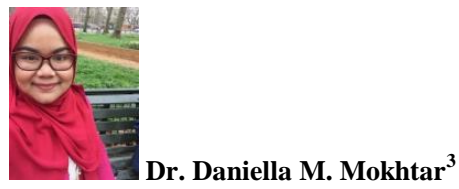

Daniella M. Mokhtar is a fellow at the School of Human and Societal Well-being (PsiTra), Faculty of Social Sciences at The National University of Malaysia (UKM). She teaches and does research in Occupational Health Psychology, Bullying, Perseverative Cognition, Workplace Incivility and Coping.

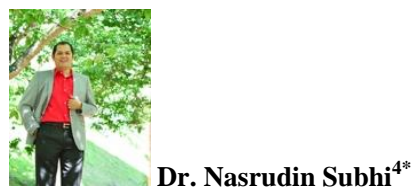

Nasrudin Subhi is currently a senior lecturer at the School of Human and Societal Well-being (PsiTra), Faculty of Social Sciences at The National University of Malaysia (UKM). He teaches and does research in the area of work that covers Counselling Psychology, Sexuality, Resilience, Qualitative Method, Indigenous Community, At-risk youth, Women Leadership. 